

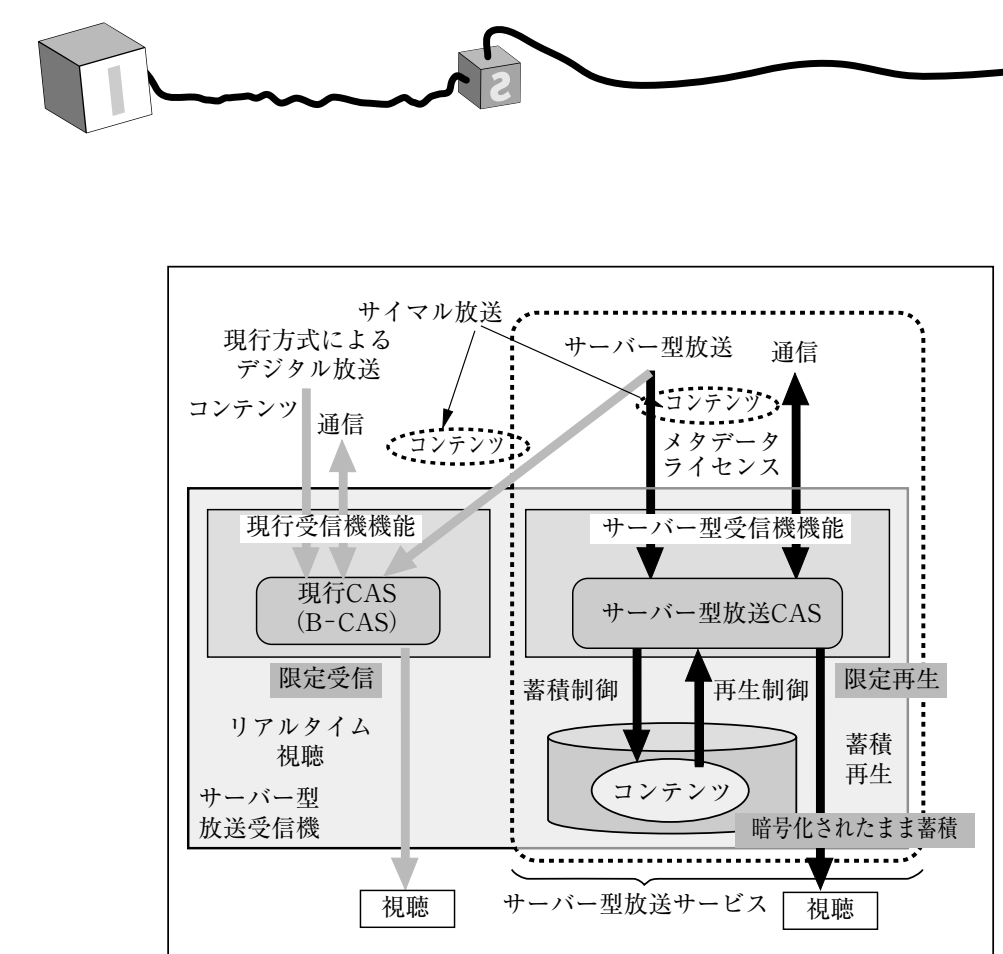

図1 サーバ一型放送のサービス環境

\section{4 コンテンツの取り扱い}

\section{1 サーバー型放送のサービス環境}

サーバー型放送のサービス環境を図1に示す. 現行方式 の限定受信方式を用いたリアルタイム視聴機能に加えて, サーバー型放送機能が搭載された受信機は, 伝送路として

は，放送とブロードバンドの常時接続環境を想定する.

ここでは受信機に必須な機能を通して，サービス環境を説 明する. 以下がサーバー型放送受信機に必要な機能である.

(1) デジタル放送受信機能：デジタル放送受信機のフロ ントエンド機能として, 放送波からTSを取出すまで の機能.

(2) 通信機能：ブロードバンド回線に接続して，コンテ ンッやライセンスを入手したり, 受信機内に蓄積さ れたコンテンッやメタデータを他の機器に引き渡し たりするための機能.

(3) 大容量蓄積機能：受信機に内蔵または外付けされた ディジタル蓄積メディアを利用した蓄積/再生機能.

（4）権利保護機能：コンテンッとともに伝送されるコン テンツの利用条件に基づき，不正コピーなど権利者 の許諾に基づかない利用からコンテンツを保護する 適切な方式や機能を実現する機能.

（5）視聴制御機能：放送とともに伝送される，もしくは 通信によって取得できる，ライセンスにしたがって 蓄積されたコンテンツを再生する機能. 予め受信機 内の大容量蓄積装置に蓄積されたコンテンツをユー ザが利用する際に課金するなど蓄積後再生時の視聴 制御を実現する。

\section{2 コンテンツの分類}

サーバー型放送では，リアルタイム視聴することができ る従来の放送を，サーバー型放送として受信機に蓄積する
表1 TYPE1コンテンツとTYPE2コンテンツ

\begin{tabular}{|c|c|c|}
\hline & TYPE1コンテンツ & TYPE2コンテンツ \\
\hline 視聴形態 & リアルタイムで視聴可能 & 蓄積後にのみ視聴可能 \\
\hline $\begin{array}{l}\text { 伝送方式および } \\
\text { 伝送内容 }\end{array}$ & $\begin{array}{l}\text { 現行の放送と同様に, } \\
\text { MPEG-2のAVストリーム } \\
\text { をTS型式で伝送 }\end{array}$ & $\begin{array}{l}\text { 放送:データカルーセル伝 } \\
\text { 送 (DSM-CC) } \\
\text { 通信：ダウンロードまたは } \\
\text { ストリーミングTTSファ } \\
\text { イル, モノメディア符号化 } \\
\text { コンテンツ, BML, メタデ } \\
\text { ータなどのファイル }\end{array}$ \\
\hline 蓄積管理と利用 & $\begin{array}{l}\text { 受信機内でTTSファイル } \\
\text { に変換して蓄積セグメン } \\
\text { テーションメタデータが } \\
\text { 指定する特定のポイント } \\
\text { を参照可能 } \\
\end{array}$ & $\begin{array}{l}\text { ファイルとして蓄積. 例え } \\
\text { ば,BMLからモノメディア } \\
\text { やTYPE1コンテンッを参 } \\
\text { 照して表示するなど }\end{array}$ \\
\hline ライセンス伝送 & $\begin{array}{l}\mathrm{EMM}(\text { メインライセンス\& } \\
\text { ワーク鍵 }(\mathrm{Kw})) \text { と Kc伝送 } \\
\text { 用 } \mathrm{ECM}(\text { サブライセンス+ } \\
\text { コンテンツ鍵 }(\mathrm{Kc})) \text { によ } \\
\text { る2階層ライセンス }\end{array}$ & $\begin{array}{l}\text { ACIにてデータカルーセル } \\
\text { で伝送される } \\
\text { 通信経由の伝送では一階層 } \\
\text { ライセンス (個別ライセン } \\
\text { ス)も可能 }\end{array}$ \\
\hline
\end{tabular}

ことで，従来の録画機における単純なタイムシフト視聴を 超える，ダイジェスト視聴のような多様な視聴形態を提供 する。これにより，ハイビジョンなどの高品質なコンテン ツでも，通常の放送の帯域を有効に活用することができる 利点がある．図1において，サーバー型放送から現行受信 機能に斜めに信号が供給されているが，これはその観点か らの信号の流れである。このように，リアルタイム視聴が 可能で蓄積後にダイジェスト視聴などが可能となる映像音 声 (AV) は，受信機でタイムスタンプ付きTS (TTS) ファ イルとして蓄積され, 受信時に生成されるセグメンテーシ ヨンメタデータから指定されたセグメント位置を判断する ための付加情報とともに管理される.

一方, 放送中は視聴できないが，ファイルとして伝送し， 蓄積完了後に利用するという方法も考えられる. 放送では, DSM-CCのカルーセル伝送によって，コンテンツを伝送し， 受信機は所定のファイルを受信，蓄積する.

このような二つのコンテンッの形態を，サーバー型放送 に扔いては，前者をTYPE1コンテンッ，後者をTYPE2コ ンテンツと呼ぶことにした。 それぞれの特徴を表1にまと める.

なお，通信経由でも放送と同様に，通信サーバ上の TYPE2 コンテンツをダウンロードして蓄積利用，または久 トリーミングで，リアルタイム視聴で利用する.

\section{3 サービスパタンとサービス例}

実際の放送の中でのサーバー型放送の編成については, いくつかのサービスパタンで整理した．図2にその五つの パタンを示す。図中11は, 独立TYPE2コンテンツ伝送 (新 規独立型サービス）である．現行方式の受信機では認識で きないTYPE2コンテンツを，データカルーセル伝送する蓄 積専用サービスである．現行放送内容とは独立したさまざ 


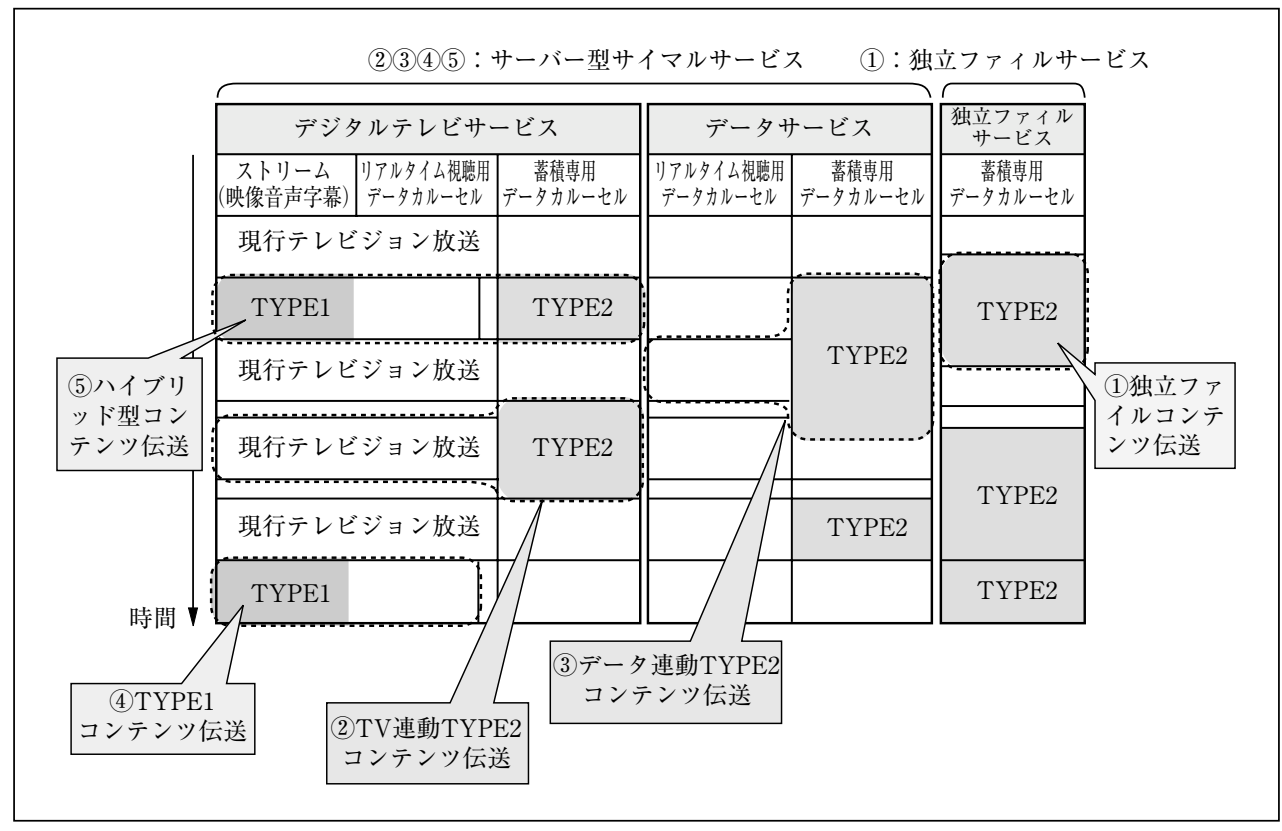

図2 サービスパタン

まな種類のコンテンツをダウンロードすることができ，例 えば，ビデオクリップや出版コンテンツなどの配信に利用 され, 蓄積予約により蓄積されるサービスが想定される. 蓄積予約は, 蓄積されたBMLポータル画面やEPGなどから 行う.

(2)のテレビ連動TYPE2コンテンツ伝送と (3)のデータ連動 TYPE2コンテンツ伝送は, それぞれ現行のテレビサービス や独立データ放送に連動した, 蓄積専用のデータカルーセ ルによるコンテンツ伝送である.これらは, 放送中のBML コンテンツからユーザの直接指示に従い, 現行放送サービ ス内の一部で伝送するTYPE2コンテンツを蓄積して利用す る「現行放送付加型のサービス」を提供する．すなわち，リ アルタイム視聴用のBMLコンテンツから，ユーザが放送中 のコンテンツに関連した映像コンテンツや音楽クリップな どを逐次蓄積を行うという動作となる．このため蓄積予約 は行えない.

(4)のTYPE1コンテンツ伝送は, 通常のテレビサービスに, 蓄積制御情報とTYPE1アクセス制御用のECM/EMMが付 加された形態のコンテンツ伝送である. 別途, サーバー型 放送として利用するためのBML等を蓄積して利用すること になる．また，5はハイブリッド型コンテンッ伝送であり， TYPE1コンテンツとTYPE2コンテンツを同時に伝送する. 蓄積予約または番組視聴中に視聴者からの蓄積指示により 蓄積される．蓄積後はTYPE2コンテンツからTYPE1コン テンツを参照して利用する.この(4)と(5)は, 蓄積予約に従 い, リアルタイム視聴可能なTYPE1コンテンツと, 同時ま たは別途蓄積されたTYPE2コンテンツ（メタデータ含む） と組合せて利用する高度連動型サービスである. 現行放送 では実現できない付加価值をもたせることにより, サーバ
一型放送の特徵を最大限に生かしたさまざまな視聴スタイ ルの提供が可能となる。この場合, 蓄積されたBMLポータ ル画面やEPG/ECGからコンテンッの蓄積予約を行うこと が想定される.サービス例として，メタデータを利用した ダイジェスト視聴などの高度な視聴形態が考えられる。

なお，(2)〜 (5) AVコンテンツ等について現行放送と共 用するサイマル運用 (同時運用) で行われる.

\section{4 リソースの分類と利用単位コンテンツ}

サーバー型放送の蓄積対象となる最小の単位をリソース と呼ぶ.リソースは, 実際に再生視聴される提示リソース と，提示リソースを制御するための制御リソースに分類さ れる. 提示リソースとしては，以下がある.

(1) ストリームリソース：MULTI2でスクランブルされ たTS (TYPE1アクセス対象) およびAESで暗号化 (エ ンクリプト)されたTS (TYPE2アクセス対象)のいず れか. なお，映像や音声の符号化は現行方式で規定 されているMPEG-2の映像音声符号化方式である.

(2) マルチメディアリソース：BML文書.

(3) モノメディアリソース : JPEG, PNGなど, ARIB STD-B247) で規定されたファイル形式とする.

また制御リソースとして, TYPE2のライセンスを伝送す るACI (Account Control Information), コンテンツの起動 に必要な情報を伝送するERI(Entry Resource Information), 利用単位コンテンツ起動時にライセンス情報を示すLLI (License Link Information)，トリックプレイ区間制御情報 を示すTSI (Trickplay Segment Information)などがXML型 式のファイルで定義されている.

サーバー型放送では, 特定の放送番組で得られたコンテ ンツとともに，他の放送時間帯や通信を使って得られた 


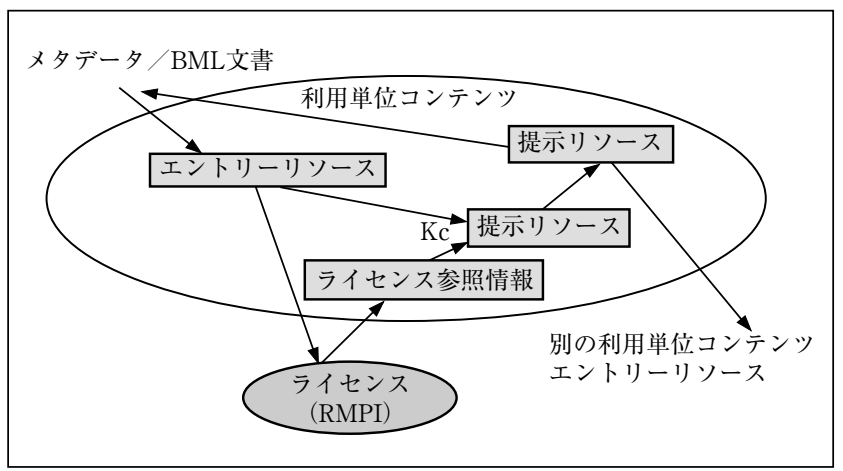

図3 利用単位コンテンツ
AVコンテンツ，メタデータさらにはライセンスなどを一 括りとして再生を行うことになる。この再生の単位を, 「利用単位コンテンツ」として, 従来の放送でのコンテンツ とは区別する概念を導入した。利用単位コンテンツの単位 で一つのコンテンツの利用条件 (RMPI: Rights Management and Protection Information)の対象とするこ とから, 再生の単位は換言すれば課金の単位でもある.こ の利用単位コンテンツは, 蓄積メディア上では, コンテン ツ参照ID (Contents Reference ID: CRID) で参照される.

利用単位コンテンツの概念を図3に示す．利用単位コン テンツの要素としては, エントリリソース, そして複数の 提示リソース，制御リソースがある.

BMLを含むマルチメディア利用単位コンテンツでは, 暗 号化されないERIがただ一つ存在する.このERIの記述に 基づいて，ライセンスに関連した処理を行う。すなわち， ライセンスをLLIに記載されたURIにて確認し, 必要に応 じてライセンスの取得を行う。また，デスクランブルやデ クリプトに必要となる鍵をレンダラ (暗号化コンテンツを 処理する受信機の機能ブロック)に設定する. この後, 起 動リソースの再生が開始される. 再生時は, RMPIに基づ いて再生制御が行われる.

利用単位コンテンツは, 他の利用単位コンテンツの参照 や遷移が可能である.すなわち，BMLを含む利用単位コン テンツから, TYPE1コンテンツからなる利用単位コンテン ツを参照して, BMLの表示ウィンドウ中に映像をはめ込ん で表示するなどである.

サーバー型放送では，BMLによって放送事業者の意図す るコンテンツの表示やさまざまな制御を行う。このため,
現行方式の放送で利用されたBMLを, サーバー型放送に合 わせて拡張した。拡張された機能としては, 蓄積機能, 予 約蓄積機能, ライセンス関連機能, CAS関連機能, 利用単 位コンテンツ管理機能, 再生制御関数, メタデータ参照機 能, 双方向機能などである.

\section{5 コンテンツの伝送と受信機での蓄積}

放送または通信で伝送されたコンテンツやライセンス は, 放送局が想定する管理体系にしたがって受信機に蓄積 して利用される.したがって, その蓄積の論理的な識別, 蓄積されるファイル名に相当するCRIDや蓄積されるディ レクトリはSIや各種制御リソースで与えられる条件に従っ たユニークな体系に従わなければならない.このため, 蓄 積については以下の通り規定している.

(1) 番組の蓄積はイベント (番組) 単位すなわち, イベン トの開始から終了まで行われる.

(2) TYPE1コンテンツの蓄積対象となるESは, サービス に含まれるすべての映像, 音声, 字幕のESである.

(3) 蓄積は, モノメディアやメタデータ等のファイルや TTSファイルとして行われる. 蓄積はアクセス制御 の基本的な考え方に則って，スクランブル/エンクリ プト状態のまま行われる.

(4) 事業者毎に利用単位コンテンツの名前を特定するた めにAuthorityが運用される。この下に利用単位コン テンツのディレクトリが配置されていく.

（5）蓄積する論理パス (ディレクトリ)は, TYPE1コンテ ンッではEIT内の記述子に, TYPE2ではDII (Download Information Indication)に記載される. また, 同記述子内に, コンテンツをユニークに特定 するCRIDを記載する。

\section{5 \クセス制御方式とコンテンツ利用条件}

現行方式の放送では，受信後直ちにコンテンツのスクラ ンブルを解除して視聴しており，録画についてはこのまま コンテンツが録画され, 私的録画としてタイムシフトでの 視聴が可能となる.この場合, 録画後のコンテンツの視聴 を権利保護の観点から制御することはできない. 一方, サ ーバー型放送では，コンテンツに施された暗号を解除せず に蓄積し, 視聴の都度コンテンツに付加されたライセンス として伝送された権利保有者が指定する視聴条件に則っ て, 暗号の解除を行うという形態を取る.

表 2 アクセス制御方式の分類

\begin{tabular}{|l|c|c|c|c|c|}
\hline \multicolumn{1}{|c|}{ 分 類 } & 放送受信時視聴 & 蓄 積 & 暗号化 & $\begin{array}{c}\text { アクセス制御の } \\
\text { ための共通情報 }\end{array}$ & $\begin{array}{c}\text { アクセス制御の } \\
\text { ための個別情報 }\end{array}$ \\
\hline \hline $\begin{array}{l}\text { TYPE1アクセス } \\
\text { 制御方式 }\end{array}$ & 可 能 & $\begin{array}{c}\text { 可 能 } \\
\text { (アクセス制御) }\end{array}$ & $\begin{array}{c}\text { スクランブル } \\
\text { (MULTI2) }\end{array}$ & $\begin{array}{c}\text { Kc伝送用ECM, } \\
\text { ECM-Kc }\end{array}$ & EMM \\
\hline $\begin{array}{l}\text { TYPE2アクセス } \\
\text { 制御方式 }\end{array}$ & 不可能 & 蓄積が前提 & $\begin{array}{c}\text { エンクリプト } \\
\text { (AES128) }\end{array}$ & ACI & EMM \\
\hline
\end{tabular}


表2に, TYPE1/TYPE2コンテンツのアクセス制御の方 式を比較する。ここでは, 放送によるライセンス伝送の例 を取り上げている，TYPE1では，現行方式と同様に， MULTI2によるスクランブルを用いる。 ただし現行方式の ように，スクランブル鍵 $(\mathrm{Ks})$ をワーク鍵 $(\mathrm{Kw})$ で暗号化し てECMで伝送するのではでなく，イベント単位で変更され る可能性があるコンテンツ鍵 $(\mathrm{Kc})$ を導入して, 利用単位 コンテンツ毎のアクセス制御を可能にしている. 放送では, Kc伝送用ECMによって, Kwで暗号化されたKcを伝送し, ECM-KcによってKcで暗号化された Ksを伝送する。 TYPE2 コンテッでは, 128ビットのAESによる暗号化 (エンクリプション)を用いる.この鍵は放送ではACIによ って伝送される.

コンテンツの利用条件 (RMPI) は, 鍵とともにライセン スとして送られ，例えば以下のような項目が設定できる.

(1) コンテンツの視聴回数, 期限, 期間

(2)トリックプレイの可否

（3）ドメインの管理要件

(4) 再生時の外部出力

(5) 外部書き出しの制御

(6) セグメンテーションメタデータの正当性の識別

アクセス制御の詳細については，本特集の別稿に譲る.

\section{6 メタデータ}

サーバー型放送を特徵づける要件の一つがメタデータで ある.メタデータは, コンテンツに関わるさまざまな情報 を放送事業者から受信機に送り，蓄積制御のため，また蓄 積後のコンテンツを活用する目的で提供される. メタデー 夕の基本的な考え方や体系については，TVAにおいて検討 が行われ，日本でもすでにARIB STD-B383)での規定があ るが，運用規定ではさらに細かい規定を設けている.

メタデータの定義は, ARIB STD-B38において, “コンテ ンツの内容や再生の順序などを示すデータで，一般には夕 イトルやジャンル, 番組概要等のコンテンツに関するデー 夕を言う”とされている．実際に利用されるメタデータは， 記述言語型メタデータを用いるが, 情報要素によって分類 すると，運用規定で利用する範囲は以下に分類される.

(1) コンテンツ記述メタデータ：コンテンツに関するタ イトル，ジャンルなど含む一般的情報を記載.

(2) インスタンス記述メタデータ：放送日時，ロケーシ ヨン，映像フォーマットなどの配信パラメータ等を 記載.

(3) セグメンテーションメタデータ : 番組内のシーンな どのセグメント毎に, 開始時間, 継続時間, ジャン ル，キーワードなどを記載.

さらに，運用規定においては，新たに利用用途による分 類を規定した.すなわち，

(1) パブリックメタデータ：利用単位コンテンッに含ま
れないメタデータで, 受信機が直接使用可能である. 暗号化されない。例えば，受信機が蓄積予約を行う ために番組の内容を示す情報を送る等の利用方法が ある.

(2) プライベートメタデータ：利用単位コンテンツの1リ ソースで，アクセス制御対象. 例えば，セグメンテ ーションメタデータをプライベートメタデータとし て伝送し，放送事業者が指定するシーンでのダイジ エスト視聴が可能になるなどの利用方法がある.

メタデータの伝送は，ファイルの一つとして行われる. このため放送では，その他の提示リソースなどとともに DSM-CCカルーセルにより伝送され，また通信では，サー バに置かれ，ダウンロードされる.

メタデータの詳細についても, 本特集の別稿に譲る.

\section{7 通信の利用}

サーバー型放送における通信機能は，放送通信連携のた めに必須の機能である．基本的には，地上デジタル放送の 双方向通信の機能として規定されているデジタル放送受信 機のEtherポートや, IP通信によるファイルダウンロード をべースとして規定されている。これによって，通信ネッ トワーク経由でコンテンツや各種リソースの取得, 提示, 利用が可能となる. 運用規定では通信機能として, 以下の 範囲を定めている.

（1）放送が起点となって，通信ネットワーク経由でさま ざまなサービスを提供すること

(2) ネットワーク経由で, サーバ上にある必要なコンテ ンツ, リソース，ライセンスをダウンロードにより 取得し, サーバー型放送の蓄積メディアに放送から 取得したと同様に蓄積管理し，利用できること

(3) サーバ上のBMLコンテンツの表示

(4) ネットワーク経由で, サーバ上にある必要なAVリソ ースにアクセスし，ストリーミングによりリアルタ イムで提示できること

(5) パブリックメタデータの配信

(6) 検索機能

これらを実現するための通信のプロトコルやシーケンス については, 基本的にはhttp (s)によるダウンロード, rtp によるストリーミングである，対象となるファイルは，利 用単位コンテンツまたは各種リソースである.

ダウンロードの開始の際, 制御リソースの一つである DRI (Download Resource Information)によって, 必要な ファイル名やパスを認識して, ダウンロード後の利用単位 コンテンツやリソースが受信機内で蓄積される位置を知る ことができる.

また，ストリーミングを行う際，ERIに記載されたLLIに よってライセンスを認識して, rtpによるストリーミング を開始する，ストリーミングを利用する際，制御リソース 

言語, 再生時間などコンテンツの内容に関する情報に加え て, コンテンツのパッケージ情報, 価格なども提供される. また, CASの処理内容である, コンテンツの利用条件, ラ イセンスの消費状況などもECG上で表示することができ る. 図5にECGの表示概念を示す.

\section{「9むす む゙}

サーバー型放送は, 放送という信頼性が高く太い伝送路 と, 通信という多様で柔軟性の高い伝送路を用い, さらに 蓄積機能によって時間を遡る機能を組合せることで，コン テンツの新たな提供環境を創出する. 最先端のディジタル 技術を用いることで, 同時性, 同報性を特徴とするこれま での放送サービスが新たな特徴を持つことになり, 視聴者 の放送に対する不満を解消して, 新たな受益感を高めるこ とも可能となる.

サーバー型放送により，デジタル放送やブロードバンド ネットワークの普及促進，また高品質で多様なコンテンツ の合理的な流通に繋がる基盤が確立される. サーバー型放 送を通して，ディジタルテレビが家庭における総合情報端 末としてますます有効に活用されることを期待したい.

最後に，運用規定策定に当たっては，本稿執筆にあたっ たサーバーP主査, 主任の他に多数の方が検討やドラフテ イングに携わっていただいた。また，サーバーPでの運用 規定の技術検討にあたって, 前提となる要求条件の策定や 権利保護の議論が別の分科会を構成して精力的に進められ た.さらに, CAS方式については, CAS協議会で検討され た内容から運用規定に必要な要件を盛り込んだ。運用規定 公開に向けてはARIB関係者にもご尽力いただいた。これ ら多数の関係者の努力の元に, 運用規定はとりまとめられ た.この場を通じて謝意を表したい.

(2006年2月9日受付)

\section{〔文 献〕}

1）栗岡, 柳川, 福田, 長尾：“サーバー型放送”, 映情学誌, 58, 5, pp.647 650 (May 2004)

2）情報通信審議会 サーバー型放送システム委員会 報告書（平成14年9月 30日公表）http://www.soumu.go.jp/s-news/2002/020930_4.html

3）ARIB STD-B38：“サーバー型放送における符号化, 伝送および蓄積 制御方式”, 標準規格

4）ARIB STD-B25：“デジタル放送におけるアクセス制御方式”，標準 規格
5）ARIB TR-B14：“地上デジタルテレビジョン放送運用規定”

6）ARIB TR-B15：“BS/広带域CSデジタル放送運用規定”

7）ARIB STD-B24：“デジタル放送に扔けるデータ放送符号化方式と伝 送方式”, 標準規格

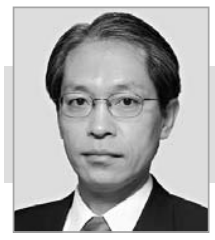

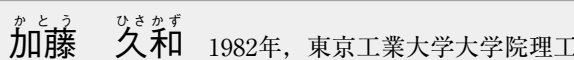
学研究科修士課程修了. 同年, NHK入局. 1985年よ り，放送技術研究所にて，BSデジタル放送の伝送方 式の開発执よび規格化, 1998年から, 技術局にて, デジタル放送の設備整備等に対応. 現在, 技術局計 画部にて, デジタル放送の標準化等に従事. 工学博 士. 正会員.

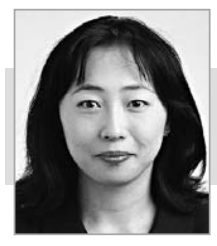

篙橋架和子 1991年, 東京工業大学大学院理工 学研究科修士課程修了. 同年, (株) フジテレビジ ヨン入社. 1993年より, 技術局企画開発部にて, 画 質評価方式, BS・地上デジタル放送，サーバー型放 送，コンテンツ保護技術等国内外の標準化活動に従 事. 正会員.

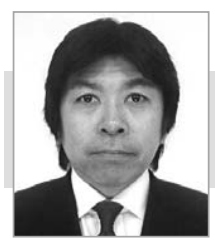

內海 憼博 1990年, 東北大学大学院工学研究 科電子工学専攻修士課程修了. 同年, キヤノン（株） 入社，通信関連の開発に従事した後，1997年に， （株）東京放送に入社. 同技術局にて, 衛星伝送設 備構築および運用業務を経て，2001年より，サーバ 一型放送, デー夕放送, ブロードバンド関連の企画 開発に従事.

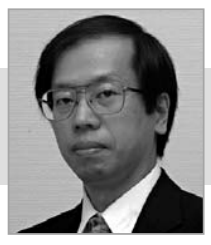

亲成势辰弥 1986年, 東北大学大学院工学研究 科電気及通信工学修士課程修了. 同年, NHKに入局. 1989年より, 放送技術研究所にて, マルチメディア 記録システム，ホームサーバ，サーバー型放送方式 の研究開発抢よび標準化に従事. 2004年より, 視聴 者技術センター（視聴者技術計画）チーフエンジニ ア. 1999年, 研究奖励賞受賞. 正会員.

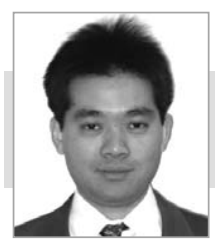

福笛賢治 1991年, 電気通信大学通信工学科 卒業. 同年, (株) WOWOW入社. 主に, 設備計 画・調達業務・標準化活動に従事. 2003年, 早稲田 大学国際情報通信研究科修士課程修了. 現在, 経営 企画局にて, 経営戦略・新規事業などの企画業務に 従事. 正会員.

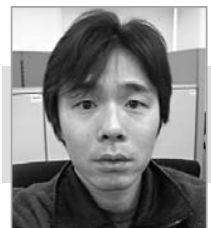

藤田健—去 1992年, 慶応大学理工学部卒業. 同年, 松下電器産業（株）入社. 現在, ネットワー ク開発センター所属. 主な研究専門分野は, デジタ 儿放送多重化, SI/EPG分野, 蓄積型放送分野. 